\title{
A BUDAPESTI 14-19 ÉV KÖZÖTTI KOROSZTÁLY ÉLETKÖRÜLMÉNYEINEK VIZSGÁLATA ESETTANULMÁNYOK ALAPJÁN
}

\author{
(Research on the Living Conditions of the 14-19 Age Group \\ in Budapest with Case Studies)
}

\section{UZZOLI ANNAMÁRIA}

\section{Problémafelvetés}

A magyar egészségügy válságba került, a mortalitási és morbiditási statisztikák évtizedek óta romlanak. A magyar népesség egészségi állapotának vizsgálata során figyelembe kell venni azokat a belső és külső tényezőket, melyek együttesen gyakorolnak hatást az egészségi állapot alakulására.

Maga az ember mint belső tényezö felelős életkörülményeinek kialakitásáért. Az egészségügyi panaszok értelmezésében, a betegségek felismerésében, a megelőzésben, a gyógyítás folyamataiban, a rehabilitációban, az orvos-beteg kapcsolatban stb. döntő fontosságú az egyén ismerete, tapasztalata, szubjektív véleménye és döntéshozatala. A külső tényezők az egyénen kívüli körülmények. Ezek a társadalmi hatások a társadalmi környezetben érvényesülnek. Az iskolai végzettség, a foglalkozás, a jövedelemszint, a lakókörnyezet, a lakáskörülmények a szociális helyzet és az életkörülmények alakulásában meghatározóak. Az egészségügyi ellátás is külső tényezö.

Jelen tanulmány a fiatal, 14-19 év közötti korosztály lakáskörülményeit, életmódját és egészségi állapotát vizsgálja. Célja, hogy bemutassa azokat, amelyek a fiatalok életminőségét jelentősen befolyásolják, és amelyek a későbbiekben még meghatározóak lehetnek. Ezek az egészségügyi kockázati tényezők elözetes hipotéziseink alapján a következők:

- A család szociális helyzete (a lakáskörülmények, a jövedelemszint) determinálja a fiatalok életkilátásait is.

- A fiatalok életmódja (a mozgáskultúra, az egészségkárosító magatartásformák) szoros összefüggésben van az egyén értékrendjével, mely a család értékközvetítésének eredménye.

- A lelki problémák, neurotikus panaszok (pl. félelem, szorongás, depresszió, tartós hangulatváltozás, lehangoltság, fejfájás [Kopp-Ratkóczi 1989]) tömeges megjelenése a fiatal korosztálynál felnöttkorban legtöbbször súlyos betegségek kialakulásához vezet.

A 14-19 évesek életkörülményei (lakáskörülmények, életmód, egészségi állapot) vizsgálatának legfőbb oka az volt, hogy az elöbb felsorolt kockázati tényezők már ebben a korosztályban is erős differenciációt mutatnak. A későbbiekben a különb- 
Uzzoli Annamária : A budapesti 14-19 év közötti korosztály életkörülményeinek vizsgálata esettanulmányok alapján.

Tér és Társadalom 14. évf. 2000/2-3. 229-237. p.

TÉT XIV. évf. 2000 2-3

ségek a társadalmi rétegződés alapját képezik. Ezek a fiatalok nem indulnak egyenlö eséllyel az életbe!

A vizsgálat ${ }^{1}$ esettanulmányokra épül, az eredmények alkalmasak az összehasonlításra ill. a további kutatások folytatására.

\section{A vizsgálat módszertana}

A tanulmány a területi különbségek értelmezésére, az egyéni tapasztalatok és megfigyelések vizsgálatára, valamint az életkörülmények és az egészségi állapot közti összefüggések keresésére támaszkodik. A társadalmi környezet különbségei nagymértékben hatást gyakorolnak az ott élö emberek körülményeire. Ez az okokozati összefüggés már gyerekkorban ill. a fiatalkorban tapasztalható. A fiatal, jórészt középiskolás korosztály fogékony az új információkra, nyitott az öket körülvevő világ problémáinak és kérdéseinek megismerésére. Élményeiken alapuló világképük jellemző korosztályi sajátságokkal bír.

Az empirikus vizsgálatok három budapesti iskolában, a Xántus János Idegenforgalmi Középiskolában ${ }^{2}$, a Zöld Kakas Líceum Mentálhigiénés Szakközépiskolában ${ }^{3}$ és az Erdélyi utcai Általános Iskolában ${ }^{4}$ történtek 2000. március-április hónapjaiban. A két középiskolában kérdőives felmérésre került sor: a kérdöív 38 kérdése vonatkozott az alapadatokra (lakcím, életkor, nem stb.), a lakáskörülményekre (komfortfokozat, családtagok száma stb.), a lakókörnyezetre (zöldterületek állapota, környezeti ártalmak), a közlekedési szokásokra, a jövedelemszintre, az egészségi állapotra (panaszok, panaszok kezelése) és a szabadidős tevékenységekre. A tanulók a kérdőíveket a tanórán felügyelet mellett töltötték ki kb. 20-25 perc alatt. A kis létszámú mentálhigiénés középiskolában a kérdőív kitöltésének napján 50 tanuló tartózkodott, mindannyian részt vettek a felmérésben. Az idegenforgalmi középiskolában véletlenszerúen kiválasztott két osztály teljes létszámával történt a felmérés, $50 \mathrm{db}$ kérdőív kitöltése. A VIII. kerületi, józsefvárosi általános iskolában a vizsgálat módszere interjúkészítés volt: a 14. életévüket már betöltött és véletlenszerüen kiválasztott hét tanulóval folytatott beszélgetések témái kapesolódtak a kérdőív kérdéseihez. Az interjúk nagyobb betekintést nyújtottak e józsefvárosi fiataloknak az életébe.

A mintavétel három csoportja elkülönül egymástól, elsősorban a fiatalok szociális helyzete és lakókörnyezete alapján. Az idegenforgalmi iskola tanulói jobb szociális körülmények között élö fiatalok. A mentálhigiénés iskola tanulói pszichés problémáikat tekintve alkotnak homogén csoportot, szociális helyzetüket tekintve nagyobb a szórás köztük. A józsefvárosi iskola tanulói a józsefvárosi problémákat prezentálják mind etnikai hovatartozásuk, mind életkörülményeiket tekintve.

A kérdőívek és az interjúk eredményeinek feldolgozásában és összehasonlításában a hipotézisekre épülő szempontrendszer segített: Hogyan ítélik meg a fiatalok lakóhelyüket? Miként befolyásolja a család helyzete a fiatalok életmódját? Mi az összefüggés a lelki problémák és az életkörülmények között? A kiválasztott három mintavételi csoport sem létszámában, sem a mintavétel mélységében nem repre- 
Uzzoli Annamária : A budapesti 14-19 év közötti korosztály életkörülményeinek vizsgálata esettanulmányok alapján.

Tér és Társadalom 14. évf. 2000/2-3. 229-237. p.

TÉT XIV. évf. 2000 -2-3

A budapesti 14-19 év közötti korosztály... 231

zentativ. A csoportokkal készített vizsgálatok tájékoztató jellegủek, segítségükkel megismerhetjük azokat a problémákat és aktuális kérdéseket, amelyek ennél a korosztálynál jelennek meg. Maga az egész felmérés próbafelmérésnek tekinthető.

\section{A lakóhely megítélése a fiatalok szempontjából}

A lakáskörülmények, a lakókörnyezet minősége, a lakóhely társadalmi összetétele nagymértékben hatást gyakorol az adott társadalmi környezetben élö emberek életminőségére. A lakóhely tekintetében jelentős különbségek vannak Budapest egyes területei között. A különbségek bemutatásának egyik módja, ha a lakosok lakóhelyükről alkotott véleményét és szubjektív megitélését vizsgáljuk. Különlegességet ad, ha a 14-19 év kơzötti korosztályt szólaltatjuk meg, hisz véleményalkotásuk kevésbé ismert.

A VIII. kerületi iskolában készített interjúk a józsefvárosi problémákról tájékoztattak: a fiatalok lakáskörülményei egyben családjuk szociális helyzetéröl is jelzésértéküek. Ezek a fiatalok Józsefváros leginkább leértékelödött kerületrészében élnek, ugyanis Középső-Józsefvárosban az Erdélyi u.-Mátyás tér-Koszorú u.-Baross u.Fiumei út-Népszínház u. által határolt rész a legalacsonyabb státusú az épület- és lakásállomány, valamint a cigány és a szegény népesség arányai szempontjából ( $L a$ dányi 1992). Az ebben a környezetben élö családok kb. 8-10 éve költöztek fel a kerületbe valamilyen válság sújtotta területröl (Nógrád, Szabolcs-Szatmár-Bereg megyébỏl stb.). A felköltözés óta átlagosan kétszer-háromszor költöztek a kerületen belül. Ezeknek a migrációknak a végső fázisa legtöbbször egy kisebb és rosszabb minőségü lakásba való beköltözést jelentett Középső-Józsefvárosban. Úgy tünik, hogy a Józsefváros ezen részében élőkre általánosságban érvényes a társadalmi és szociális pozícióvesztés. Az e kerületrészben található lakások zöme 1-2 szobás, konyhával együtt $30-40 \mathrm{~m}^{2}$-nél nem nagyobbak. A legrosszabb részeken (Lujza u., Dankó u.) a lakások sem WC-vel, sem fürdőszobával nem rendelkeznek. Ezekben a lakásokban általános probléma, hogy nem elég világosak és a falak vizesek, túlnyomó részük 1-2 emeletes bérházakban található. A lakásokban átlagosan 4-5 ember lakik együtt, a gyerekeknek nincs külön szobájuk. A fiatalok elmondásaiból kiderült, hogy leginkább lakásuk közvetlen környezetét használják a mindennapokban. Kevésbé ismerik Józsefváros többi részeit. Általános volt az egyetértés abban, hogy a kerület épületei és lakásai rossz állapotúak, elhanyagolt a köztisztaság. Mégis, nem tudtak arra válaszolni, hogy min és hogyan szeretnének változtatni, hogy kellemesebbé tegyék lakóhelyüket. Megszokták a kerület környezetét, nem szeretnének elköltözni onnan. Mintha valamilyen erö fogva tartaná őket a kerületben: hasonló helyzetü és sorsú emberek élnek itt együtt, akik közel azonos értékrenddel, hagyományokkal és életmóddal rendelkeznek. Nehéz kitörni ebből a világból. Az ismerősökkel és a rokonokkal tartott kapcsolatok miatt esetleg a VI., VII., X. és XIII. kerületbe vándorolnának. Fel sem merült bennük, hogy Budára, a zöldövezetbe költöznének. 
Uzzoli Annamária : A budapesti 14-19 év közötti korosztály életkörülményeinek vizsgálata esettanulmányok alapján. Tér és Társadalom 14. évf. 2000/2-3. 229-237. p.

A beszélgetések kapcsán megállapítható, hogy az itt élö fiatalok ugyan tisztában vannak a józsefvárosi problémákkal, de felismerték a helyzet reménytelenségét. Beletörődtek a jelenlegi állapotokba, el is fogadták azokat. Nincsenek birtokában azoknak a készségeknek, melyekkel képesek lennének változtatni körülményeiken. Ezt a magatartást pedig otthon, a családtól tanulják.

A mintavétel másik két középiskolájában a fiatalok lakókörülményeiről a kérdöívek zárt és nyitott kérdései tájékoztattak. Az idegenforgalmi iskola megkérdezett tanulóinak közel fele budai kerületben lakik, a pesti lakosúak többsége pedig XIII., XIV. és XV. kerületi. A mentálhigiénés középiskolában a tanulók alig több mint 10\%-a budai, a pestiek közül többen vannak, akik a belső kerületekben (V., VI., VII., VIII., IX., X.) laknak. Mindkét iskolában a többség lakótelepi panel épületben ill. családi vagy társasházban él. A megkérdezettek 100\%-a összkomfortos lakásban lakik, ahol átlagosan 2-3 szoba található. A mentálhigiénés középiskola tanulói kisebb alapterületú és kevesebb lakószobájú lakásokban élnek. Az idegenforgalmi iskolában végzett felmérés alapján a családok kevésbé mobilak: az elmúlt 10-15 évben átlagosan egy-két alkalommal költöztek új lakóhelyre, és több köztük az olyan, aki elégedett lakása és lakókörnyezete minöségével, és nem szeretne elköltözni jelenlegi lakhelyéről. Ezzel szemben a másik iskola tanulói már többször költöztek életük során, s még jelenleg sem elégedettek lakhelyükkel. Számottevő különbségek mutatkoztak abban is, hogy milyen módon szeretnék a megkérdezettek megváltoztatni lakáshelyzetüket. Azok, akik elégedettek mostani lakókörülményeikkel, inkább csak felújítanák, átrendeznék, vagy még kényelmesebbé tennék (tetötér beépítés, padlófủtés) lakásukat. A líceum diákja azonban többször jelölték meg, hogy saját szobával bővítenék, és világosabbra változtatnák lakásukat. Érdekes, hogy közülük sokan voltak, akik ugyan nem elégedettek családjuk lakáshelyzetével, és szeretnének változtatni rajta, mégsem fejezték ki szándékaikat, véleményüket. A lakókörnyezethez való viszonyulás tekintetében mindkét iskola diákjai a közterületek tisztaságát tartják a legfontosabbnak, ezen javítanának. Véleményük szerint figyelmet kellene szentelni a lakóépületek minőségére, a légszennyezés és a zajszint csökkentésére, valamint a zöldterületek megóvására. A líceum tanulói fontosabbnak tartjåk a közbiztonság javítását.

Az elemzések nyomán körvonalazódott, hogy az idegenforgalmi középiskolában tanuló fiatalok jobb lakáskörülmények között élnek. Igen fejlett az a készségulk, hogy saját véleményt tudnak alkotni az öket körülvevő környezetröl; ez egyben jelzi azt is, hogy tájékozottak. A lakáskörülményekböl eredỏ közvetlen problémák (pl. a lakás minöségével való elégedetlenség) és közvetett problémák (a család szociális helyzete) inkább a mentálhigiénés középiskola tanulóit érintik.

A fiatalok véleményalkotása nemcsak lakáskörülményeikröl, lakókörnyezetükröl szolgáltat információkat, hanem családjuk szociális helyzetéröl is. A leértékelödött társadalmi környezetben rosszabb a családok szociális helyzete, alacsonyabb a család jövedelemszintje, magas a munkanélküliség. Ilyen környezetben az iskola ezeknek a társadalmi konfliktusoknak a gyújtöterepe lesz. 
Uzzoli Annamária : A budapesti 14-19 év közötti korosztály életkörülményeinek vizsgálata esettanulmányok alapján.

Tér és Társadalom 14. évf. 2000/2-3. 229-237. p.

TÉT XIV. évf. 2000 -2-3

A budapesti 14-19 év közötti korosztály... 233

\section{Az életmód mint szocio-kulturális tényezö}

Az életminőséget meghatározó szocio-kulturális tényezók - az életmód, a társadalmi helyzet, a szociális helyzet - területi megjelenése eléggé differenciált, a társadalmi környezet és a lakókörnyezet területi különbségeivel van összefüggésben. A család értékközvetítése hatást gyakorolhat a fiatalok kialakuló értékrendjére. Ez az értékrend a későbbiekben felelös lehet a felnövekvő fiatal képzettségi szintjéért, a társadalmi hierarchiában elfoglalt pozíciójáért.

A józsefvárosi iskolában készitett interjúk arról tájékoztattak, hogy az itt élő fiatalok a legtöbbször rendezetlen családi viszonyok között élnek. Szinte mindenki esetében elmondható, hogy a fiatalokat nem az édesapjuk neveli, sok esetben nem is tartják a kapcsolatot a vér szerinti apával. A szülők elváltak, és már a sokadik nevelőapa neveli a gyerekeket. A család fogalma a fiatalok számára általában a testvérek, féltestvérek, rokonok és félig-meddig rokonságban álló személyek tág csoportját jelenti. A családban nincs két meghatározó személy, az édesanya és az édesapa, akik összetartanák a gyerekeket, a családtagokat. Sokszor panasz érte a nevelöapákat és az édesanyákat (pl. alkoholizmus, rossz bánásmód). A család szabadidejében, hétvégenként nincsenek kỏzös programok, a gyerekeket az „utca” neveli fel. Tapasztalható, hogy e korosztály (14-19 évesek) az idősebb testvérben talál támogató személyre. Probléma, hogy az itt élő fiatalok nem nagyon mozdulnak ki lakásuk közvetlen környezetéböl. Legtöbbször a szüken vett lakókörnyezetüket használják: ott járnak iskolába, iskola után ott találkoznak a barátaikkal és ismerőseikkel, hétvégenként a közeli tereken gyülnek össze. Nincsenek zöldterületek és sportpályák, így a különböző sporttevékenységekkel kevésbé élnek. Szabadidejükben nincs olyan tevékenység, amely hobbiszerü lenne, elfoglalná öket, rendszeres testmozgásra ösztönözne. A tévénézés, a videózás, a barátokkal való együttlét válnak az életmód meghatározó tényezőivé a kerületben.

Érezhető, hogy ebben a társadalmi környezetben a család elvesztette biztonságnyújtó szerepét. A felnövekvő fiatal generáció számára nincsenek perspektívák az életben, továbbtanulásukkal kapcsolatban is bizonytalanok. Pedig ebben az életszakaszban kapott élmények egy egész életre szóló „útravalónak” bizonyulnak.

A két középiskolában másként alakul a fiatalok életmódja. „Mi tehetné jobbá közérzetedet?" kérdésünkre adott válaszokból kiderül, hogy az idegenforgalmi iskola diákjainak $60 \%$-a szerint az életmód megváltoztatása javíthatná általános közérzetüket. Véleményük szerint kevésbé lenne domináns az új környezetbe való elköltözés, ill. a lakókörnyezet megváltoztatása. Ez is a lakóhelyükkel való megelégedettségüket, a kedvezőbb társadalmi környezetet feltételezi. A jelenlegi lakás felújítása, a családi viszonyok megváltoztatása szintúgy ebből a szempontból nem hangsúlyosak. Ellenben a mentálhigiénés középiskolában a diákok kétharmada szerint a jobb anyagi köruilmények a legfontosabbak, az életmód átformálására nem fektetnek hangsúlyt. Az egészségi állapotot befolyásoló tényezók közül (környezetszennyezés, egészségtelen életmód, lakáskörülmények, családi viszonyok, anyagi helyzet) ismét meghatảrozó erejủ az életmód, a lakáskörülmények és az anyagi helyzet. A 
Uzzoli Annamária : A budapesti 14-19 év közötti korosztály életkörülményeinek vizsgálata esettanulmányok alapján.

Tér és Társadalom 14. évf. 2000/2-3. 229-237. p.

válaszok arányai hasonlóan alakultak az előző kérdéshez: a jobb szociális körülmények már lehetôséget adnak az életmód fontosságának kiemeléséhez és aztán annak átalakításához.

A szabadidös elfoglaltságra vonatkozó kérdésünkre adott válaszok körében egyetértés van abban, hogy a mai fiatalok elönyben részesítik a barátokkal való együttlétet és a zenehallgatást. Az „ülö" tevékenységek, a tévénézés és a videózás a líceum diákjai számára fontosak. Érdekes, hogy náluk jóval magasabb azoknak az aránya, akik számítógépekkel szeretnek foglalkozni. A testmozgás, azaz a sport és a kirándulás jelentősége jóval magasabb az idegenforgalmi iskola tanulóinál. A „klasszikus” szabadidős tevékenységek, mint az olvasás, mozi és színházlátogatás meglepő módon a mentálhigiénés iskola tanulói számára nyújtanak kikapcsolódást. Egyébként megállapítható a kérdőivek eredményeiből, hogy a mai fiatal korosztály kevesebb idót és energiát szentel a testmozgásnak. Kevesebb azoknak a száma, akik az iskolai testnevelés órán kívül heti legalább 2-3 alkalommal rendszeresen sportolnak. Rendkívül kevesen vannak azok, akik sportegyesületnél, kluboknál tréningeznek, versenyszerüen üznek valamilyen sportágat. Az alkalomszerü, hétvégekre koncentrálódott mozgásformák hódítanak teret a fiatalok között. Olyan új és divatos sportágakat gyakorolnak mint az aerobic, body building, kondicionáló torna, tánc. A séta, a túrázás egyre inkább háttérbe szorul. Az idegenforgalmi iskolában gyakori sporttevékenység a síelés, a tenisz, a lovaglás, az úszás és a futás.

Az életmód mint szocio-kulturális tényezỏ nemcsak arról ad információkat, hogy az egyén milyen körülmények között él és milyen a szociális helyzete, hanem bizonyos világnézetet is jelent. A jobb társadalmi és szociális környezet lehetôvé teszi ugyan az egészségesebb életmódot, de egyfajta értékvesztéssel is jár. Egymagában a kedvezöbb anyagi körülmény nem oldja meg a problémákat. A kulturális háttér, az iskolázottság és tanultság meghatározó érvényúek.

\section{A lelki problémák mint kockázati tényezők}

A lakókörnyezet, a lakóhely társadalmi környezete, a család társadalmi, kulturális és szociális helyzete, az egyéni értékeken alapuló életmód együttesen felelösek az életkőrülmények alakulásáért. Az életminőség erősíti vagy gyengíti az egészségügyi kockázati tényezőket. A kockázati tényezők közül a lelki problémák megjelenése a rossz szociális helyzettel függ össze.

Mind a kérdöívek, mind pedig az interjúk egyik nagy kérdésköre a fiatalok egészségi állapotára terjedt ki. A józsefvárosi iskolában e kérdéskörben nem lehetett konkrét információkat gyüjteni. A fiatalok nem említettek sem testi, sem lelki problémákat, melyek a mindennapi életüket érintenék. Ezzel kapcsolatban kétféle következtetés vonható le. Egyrészt ténylegesen még nem jelennek meg egészségi problémák ebben a korosztályban; másrészt ezek a fiatalok talán fel sem ismerik saját panaszaikat. Nem tanítják meg őket a panaszok helyes értelmezésére és felismerésére. Nem tudják, hogy problémáik esetén kihez fordulhatnak segítségért, nem 
Uzzoli Annamária : A budapesti 14-19 év közötti korosztály életkörülményeinek vizsgálata esettanulmányok alapján.

Tér és Társadalom 14. évf. 2000/2-3. 229-237. p.

TÉT XIV. évf. 2000 -2-3

A budapesti 14-19 év közötti korosztály... 235

ismerik azokat a megoldási lehetőségeket, melyeket alkalmazhatnának. A legnagyobb probléma számukra, hogy hol élnek és hogyan élnek.

A kérdőívekre kapott válaszok alapján megállapitható, hogy a mai fiatalok elsösorban lelki problémákkal küszködnek. Korosztályuk esetében az egészségi állapot romlása nem tapasztalható, nincsenek súlyos és krónikus betegségeik. De az állandó stressz, a lelki megterhelés, a hangulatzavarok lassan kifejtik hatásukat. Az általános egészségi panaszok közül leginkább a pszichés eredetüek dominálnak. A stressz, az idegeskedés, a fejfájás, a lehangoltság, a fáradékonyság, az alvászavarok, a félelem és szorongás érzése mindkét iskola esetében a tanulók több mint $20 \%$-át érintették. Az idegenforgalmi iskolában a diákok több mint fele panaszkodott fejfájásra, fáradékonyságra és stresszre. A mentálhigiénés iskola esetében ezek között a panaszok között nagyobb a szórás, bár a stressz mint panasz előfordulása itt is igazán jelentős. Megfigyelhetö, hogy ugyan a diákok igen súlyos lelki problémákkal élnek együtt, mégsem hajlandóak szakemberhez, szakorvoshoz fordulni. Panaszaikat nem kezeltetik, melyet valószínüleg a pszichológusokkal, pszichiáterekkel szemben tanúsított fenntartásaik, félelmeik okoznak. Ezekben a kérdésekben a családnak és az iskolának kell nekik segíteni. Erre példa a Zöld Kakas Líceum, amely kimondottan a mentálhigiénés problémákkal küszködő fiatalok megsegitésére jött létre. Nem véletlen, hogy ezen iskola tanulói között a félelem és szorongás érzése a legkevésbé fordul elő panaszként. A kérdőiv egészségi állapottal kapcsolatos kérdésköre szintén épített a fiatalok szemléletmódjára. A fiatalok saját korosztályuk egészségi állapotáról a valóságnak megfelelően nyilatkoztak. Véleményük szerint a mai fiatalok egészségi állapota nem megfelelő, ami adódik a mozgásszegény életmódból és az egészségkárosító magatartásformákból (dohányzás, alkoholfogyasztás, drogfogyasztás).

A súlyos lelki problémák nemcsak következményeik miatt kezelendők, hanem kezelésükkel a társadalmi problémák is részben napvilágra kerülnek. A fiatalok pszichés állapota reprezentatív a felnőtt lakosságra nézve. A lelki panaszok megjelenése az egészségi állapotot meghatározó külső tényezőktől függ. Azonban a panaszok felismerése és megoldása a belső tényezőktől függ. A belső tényezők hangsúlyosabbá tétele az iskolai végzettség növelésével érhető el.

\section{Konklúzió}

A tanulmány a budapesti fiatalok (14-19 év közöttiek) életkörülményeit elsődlegesen a középiskolások társadalmi rétegzỏdése alapján vizsgálta. Társadalmilag determinált már maga az is, hogy milyen társadalmi rétegek gyermekei válnak középiskolássá (Gazsó-Pataki-Várhegyi 1971). Különbség van abban is, hogy ki, milyen középiskolába kerül. Az iskolázottság mértéke a szocio-kulturális tényezök (pl. szociális helyzet) hátterében áll; a rossz szociális helyzet pedig az egyik legfontosabb egészségügyi kockázati tényezö ${ }^{5}$. Az ok-okozati összefüggés alapján megállapítható, hogy az iskolai végzettség erősen befolyásolja az egészségi állapot alakulását. 
Uzzoli Annamária : A budapesti 14-19 év közötti korosztály életkörülményeinek vizsgálata esettanulmányok alapján. Tér és Társadalom 14. évf. 2000/2-3. 229-237. p.

Középső-Józsefvárosban van a legkisebb esély arra, hogy a fiatalok továbbtanuljanak, szakmát válasszanak. Sem általános iskolai tanulmányaik (pl. évismétlések), sem lakókörülményeik (pl. nyugodt tanulásra alkalmas lakások hiánya), sem családi hátterük (pl. szülöi késztetés) nem segít nekik ebben. A kedvezőtlenebb társadalmi környezet (pl. slumosodott belső pesti kerületek, rossz közbiztonság, lakókörnyezettel való elégedetlenség) leginkább a fiatalok mentális és pszichés állapotára gyakorol hatást: ez akadályozza öket abban, hogy egy „normál” középiskolában tanuljanak. Szociális érzékenységük követeli meg speciális képzésüket. A megfelelö lakáskörülmény és lakókörnyezet jótékonyan hat az iskolai tanulmányokra: lehetöség nyílik magasabb követelményeket támasztó iskolában tanulni, annak anyagi költségeit fedezni.

A vizsgálat alá vett egészségügyi kockázati tényezők - a család szociális helyzete, a fiatalok életmódja, a pszichés és neurotikus panaszok - egyben olyan társadalmi feltételek is, amelyek az egyén szubjektív alkalmazkodását mutatják be az objektiv körülményekhez. Azonban ez az alkalmazkodás legtöbbször a hibás magatartásformák felvételét jelenti. Ezeknek a kockázati tényezőknek a hangsúlyos megjelenése az ifjúság körében jelentőséggel bír a felnött lakosságra nézve is. Nemcsak a külsö körülményeken kell változtatni (lakóhely, jövedelem, foglalkoztatás), hanem az életszemléleti harmóniára kell törekedni. Amennyiben ezt a családok nem tudják megvalósítani, úgy az iskoláknak szükséges a feladatot megoldani.

Magyarországon súlyos probléma a depresszió megjelenése, amely a lakosság 76\%-át érintette 1988-ban. A depresszió legszorosabban a szív-érrendszeri betegségekkel, a gyomor-bélbetegségekkel, a mozgásszerviekkel és a fertőző betegségekkel áll kapcsolatban. A depresszió kialakulásában és annak megoldásában különösen nagy jelentösége van a tanultság hiányának (Galgóczy 1997). Mivel a fiatalok között egyre magasabb számban jelennek meg a pszichés és neurotikus panaszok, ezek kezelését már e korosztálynál el kell kezdeni. A finanszírozásra és az egészségügyi ellátásra irányuló egészségügyi reformok mellett az oktatásfejlesztésre még nagyobb figyelmet kell szentelni. A tanultság és a képzettség szociális biztonságot ad, segít megbirkózni a változó élethelyzetekkel, egészségesebb életmódra késztet.

\section{Jegyzetek}

' A vizsgálat ötlete, annak kivitelezése Földi Zsuzsával, az. ELTE TTK Doktori Iskola másodéves hallgatójával együtt történt.

${ }^{2}$ Budapest V. kerület, Markó u.: a két tanítási nyeluu iskolában a tanulók az öt év alatt technikusi képzést kapnak.

${ }^{3}$ Budapest IX. kerület, Hurok u.: az alapítványi iskolába azok a tanulók kerülnek, akik már más középiskolákból kiestek, tanulmányaikat különböz̋ okok miatt nem tuditák folytatni.

${ }^{4}$ Budapest VIII. kerület, Erdélyi u.: az iskolában a tanulók 90\%-a cigány származású, $66 \%$-a pedig túlkoros.

${ }^{5}$ Kopp Mária pszichiáter (SOTE Magatartástudományi Intézet) szóbeli közlése alapján, 1996. 
Uzzoli Annamária : A budapesti 14-19 év közötti korosztály életkörülményeinek vizsgálata esettanulmányok alapján.

Tér és Társadalom 14. évf. 2000/2-3. 229-237. p.

TÉT XIV. évf. 2000 -2-3

A budapesti 14-19 év közötti korosztály... 237

Irodalom

Galgóczy Zs. (szerk.) (1997) A tudományos kutatástól a politikai döntésig. Budapest, Konrad Adenauer Alapítvány.

Gazsó F.-Pataki F.-Várhegyi Gy. (1971) Diákéletmód Budapesten. Budapest, Gondolat Kiadó.

Kopp M.-Ratkóczi É. (1989) Budapest Jozsefváros két orvosi körzetének összehasonlító pszichiátriai epidemiológiai vizsgálata. Budapest, SOTE Magatartástudományi Intézet.

Ladányi J. (1992) Gondolatok Középsö-Józsefváros rehabilitációjáról. - Tér és Társadalom. 3-4.

\section{RESEARCH ON THE LIVING CONDITIONS OF THE 14-19 AGE GROUP IN BUDAPEST WITH CASE STUDIES}

\section{ANNAMÁRIA UZZOLI}

This research is about young people, aged 14-19, in Budapest. This essay is based on case studies which were prepared in two secondary schools and in a primary school. My main job was to work out a questionnaire and interviews with teachers and students.

I have studied what the influence is between the lifestyle and the state of health. The results are the following.

The housing conditions are important parts of the state of health among young people. Living on low salaries means living in poor housing conditions (they have to live in very small flats which are not free from dampness).

The social position of the families influences the prospects of children in their lifetime. We can say there is a big differentation of younger people.

There are many neurotical illnesses - for example depression - in this age.

In my opinion the lack of education is responsible for this situation. 